\title{
State Intervention, Globalization and the Evolution of Malaysian Banks' Identities
}

\author{
CHIN YEE WHAH
}

\begin{abstract}
This article describes and explains the evolution of Malaysia's locally owned banks in a series of mergers and acquisitions within national borders and beyond. It argues that state intervention, external economic and financial crises and the liberalization of the financial sector have compelled the consolidation of local banks in Malaysia. The consolidation process has resulted in the increased size of state-owned banks, decreased the number of local Chinese-owned banks and seen a decline in family shareholding in the remaining Chinese-controlled banks. Through regional expansion both Chinese-controlled and stateowned operations have become large-scale regionally based banking groups or global banks, deepening the financial integration in ASEAN countries.
\end{abstract}

Keywords: Chinese finance, bank identities, affirmative policy, financial liberalization and integration, ASEAN

\section{Introduction}

This article studies Malaysian banks with an evolutionary economics approach to describe changes of ownership, identities and development by analysing how state intervention and the forces of globalization have resulted in the merger and acquisition (M\&A) of Malaysia's local banks and their expansion into ASEAN countries and beyond. Under the affirmative action of its New Economic Policy (NEP), the state has been persistent in gradually consolidating Malaysia's banking industry. The state took the strongest approach and entirely reformed the domestic banking sector from the mid-1980s, when a world economic recession occurred. Next, it was the Asian financial crisis (AFC) of 1997/98 that severely hit Malaysia and four other ASEAN countries' financial sectors. To defend such affirmative action, the government's banking policy has always favoured state and stateaffiliated banks, which has resulted in the increased size of state-owned banks through M\&A. In contrast, the number of Chinese family-owned 
small and medium-sized banks has decreased over the past five decades (1970-2010). The increased liberalization of the financial sector had gradually pushed the state to formulate banking consolidation policies to create large Malaysian banking groups to compete with foreign banks. The 'double forces' of state intervention and globalization have gradually decreased family ownership of particular banks and progressively changed Malaysian bank ownership and identity so that they have become 'national banks'. Since the 2000s, Malaysian banks have aggressively expanded their presence beyond the national borders and become global operations, deepening the financial integration in ASEAN countries and beyond.

The global financial crisis (GFC) of 2008-9 created an opportunity for Malaysian banks to make good deals by acquiring foreign banks in Malaysia and also in ASEAN countries. The GFC had an enormous impact in that the near meltdown of American and European banks forced these banks to consolidate their businesses outside of home countries. Conversely, cross-border banking activity within the Asia-Pacific region has deepened since the GFC (Remolona and Shim 2015). While European banks were deleveraging, banks from emerging economies and developing countries were in their expansion mode, with some Malaysian banks acquiring European banks operating in ASEAN countries and doubling their presence (Almekinders et al. 2015; Claessens and Horen 2014). The GFC shifted foreign banks' global activities and decreased the number of domestic banks through consolidation compelled by deregulation. In contrast, banks from emerging markets increased their presence abroad during and after the GFC (Claessens and Horen 2014). These new phenomena reflect the deepening of financial integration in ASEAN by banks from ASEAN countries, which is evidenced in the expansion of banking and financial activities of Singaporean banks in the region. As one of the largest financial centres in the world, Singapore plays a leading role in regional financial integration (Almekinders et al. 2015). Malaysian banks have also expanded abroad significantly since early 2000s, which is explained in detail in this article.

\section{Studies on Malaysian Banks}

There are five important studies on the development of local commercial banks in Malaysia with emphasis on history, development, ownership and state intervention (Cheah 2011; Chen 2013; Cook 2008; Hara 1991; Tan 1953). Tan (1953) provides detailed historical records of the 
establishment and activities of the first Chinese banks in Malaya and Singapore in the early years of the twentieth century. After 1953, there was no specific study on the development of Malaysian banks until 1991 when Hara Fujio made an assessment of two decades of NEP impact on the ownership of Chinese-owned banks, revealing their decline. Cheah (2011) takes an evolutionary economics approach that traces the historical development, decline and transformation of Malaysia's early banks. He argues that the 1999-2001 Malaysia banking consolidation fundamentally transformed Malaysia's financial landscape. However, Cheah's study lacks details regarding the evolution of Malaysia's banks and does not examine the regional expansion of Malaysian banks in post2001 banking consolidation. Chen (2013) explains that the conservative policy of Chinese banks in Sarawak constrains their development and so they remain small, which has made them easy targets of acquisitions under the protracted affirmative policy of the NEP. Cook (2008) examines how the government responded to consolidate Malaysia's commercial banks in the aftermath of the AFC and in light of the increased pressure of globalization. He argues that Malaysia's banking policies are integral to the NEP and that its banking sector remains the most protected compared to other ASEAN countries.

There are several studies on the consolidation of Malaysia's banking industry in the aftermath of the AFC, such as banking restructuring process in Malaysia (Bala and Mahendran 2004; Ito and Hashimoto 2007), selecting merger partners (Balachandher 2004) and the effect of banking consolidation and competition in the Malaysian banking sector (Muhamed Zulkhibri and Fadzlan Sufian 2006).

From a management and international business perspective, Koh's (2018) study on the risk psyche of management professional argues that Malaysian Chinese-controlled banks lack intensity in terms of their awareness of new risk management techniques. Koh's findings could be different if his analysis included the important dimension of affirmative action policy. In a study of the international expansion of Malaysia's four largest commercial banks, Syed Zamberi (2012) explores the reasons and entry strategies for Malaysia's banks' growth in ASEAN countries. From an international business approach, Syed's study shows that a saturated domestic market and the growing liberalization of the financial and banking sectors in Malaysia are major push factors for large banks to find new growth markets. The international expansion pattern, process and destinations of Malaysia's commercial banks are similar, which indicates that Malaysian banks tend to follow one another's steps. This 
also indicates increased financial integration, servicing the international presence of Malaysian companies in ASEAN.

Compared to Singapore's four largest banks, which started international expansion in 1909 (Tschoegl 2001), the regional expansion of Malaysia's commercial banks to ASEAN countries is about half a century behind Singapore. One common factor in local Malaysian and Singaporean banks' expansion abroad is deregulation of the financial sector, be it in home countries or host countries, that either create more competition or increases growth market opportunities. Tschoegl's (2001) study shows four factors responsible for the international expansion of Singapore's top four largest banks', which include home and host government policies, ethnicity and family management. Out of these four factors, ethnicity and family management are not identified as responsible for the international expansion of Malaysia's state-owned banks in Syed's study (2012).

This article explains the evolution of Malaysia's five largest banks from being mainly Chinese owned to state owned and from mediumsized domestically based banks to large-scale regionally based banking groups in the ten ASEAN countries. The evolutionary economics approach applied in this study covers the formation, development, banking consolidation and regional expansion of Malaysia's commercial banks. It goes beyond the tracks laid by Tan (1953), Cheah (2011), Chen 2013, Cook (2008) and Hara (1991). This article also describes how the GFC of 2008-9 created an opportunity for Malaysia's largest banks to expand into ASEAN countries, which Syed (2012) did not examine. In addition, the article traces the evolution of Malaysia's largest banks from their formation years, while Syed's (2012) study only focuses on the contemporary development and international expansion of Malaysia's four largest banks.

\section{Conceptual Framework and Research Method}

This article traces how state intervention and forces of globalization have changed the ownership, identities, size and geographical presence of Malaysia's local banks over many decades. State intervention refers to the protracted affirmative action of the NEP, which aims to eradicate poverty and to restructure Malaysian society. One of the strategies that sets out to achieve this restructuring is wealth redistribution, with the objective to form a Bumiputra Economic Community (BEC). ${ }^{1}$ A profound intervention in the reform of the banking sector is needed to expedite the 
ascension of the BEC. Administrative power and legislative regulation are used to control and limit the expansion of foreign banks, while, for local banks, state intervention takes different forms. First, there must be the restructuring of equity ownership to match NEP targets. Second, this is done through takeover of banks that face the threat of a major bank run and through policies supportive of the new establishment and growth of bumiputera banks. Third, there must be constraining of the growth of non-bumiputera banks by limiting the issuance of banking licences. Fourth, the acquisition of Chinese-owned banks by state-owned bumiputera companies or banks through banking sector consolidation. Fifth, acquisitions of Chinese banks by state-linked non-banking entities is a factor too (see Cook 2008: 71-74).

The 'forces of globalization' refers to the liberalization and deregulation of the financial sector, which have progressively increased competition in the home country as well as creating new growth markets in other countries. These forces of globalization also include how external financial shocks such as the AFC have seriously affected Malaysian banks and how the GFC almost destroyed some major European and American banks but also created opportunities for Malaysian banks to flex their muscles in aggressive regional expansion.

Identity of banks refers to an organization's identity, focusing on the core role of an organization, its main enduring elements over time and the distinctive features and characteristics that determine how the organization is both similar to and different from others (Albert and Whetten 1985). This study examines the evolution of the original core role of early Chinese-owned banks, and their ownership structure and characteristics over time after they have become state-owned banks. Banks that remain under Chinese control share some similarities with state-owned banks in terms of diluted family shares ownership, capital size and regional expansion.

The evolutionary economics approach is used to describe phenomena that have already happened over time. In this study, an evolutionary economics approach traces the development and changes of individual firms that have different historical backgrounds, characteristics and potential. Because each firm is unique, it is impossible to make specific predictions about patterns of evolution in each one. Therefore, qualitative and interpretative methods are needed to explain how these firms have evolved. Data from previous research, company reports and press coverage are used extensively to trace the evolution of Malaysia's banks' identities. 
The five case studies in this article concern Malaysia's largest commercial banks. The case study approach is adopted to examine the evolution of these banks; although a case study is not a specific method for collecting data but is regarded as a mode of organizing data in terms of an individual example's history and development (Goode and Hatt 1952). The extended case studies methodology is applied to track the evolution of a particular bank over an extended period. Thus, it is possible to trace the changes in a bank's core role, constitutive elements and characteristics over time.

\section{History of Malaysia's Local Banks}

Most domestic banks established in Malaysia were mainly owned by and identified with the Chinese community. Early local commercial banks established in Malaya were generally based around Chinese clans. These banks were established to meet the needs of small Chinese traders. Out of the 23 commercial banks in Malaysia, 14 were established by the Malaysian Chinese (Cheah 2011).

The earliest bank incorporated in Malaya was Kwong Yik (Selangor) Bank (1913), which had its roots in Singapore. Kwong Yik Bank was the first Chinese bank founded in Singapore in 1903 by prominent Cantonese businessmen, largely aiming to benefit the Cantonese community (Tan 1953). In 1920, Batu Pahat Bank Ltd was established in Batu Pahat, Johor by the Hokkien. In 1935, Ban Hin Lee Bank Ltd (BHL) was established in Penang by a prominent Hokkien, the late Yeap Chor Ee (Tan 1953). BHL originally focused on serving local businessmen in their trading and mercantile activities. In the 1960s, BHL branched into real estate and house financing throughout Malaysia and Singapore. The Bank of Malaya that emerged out of mining activities in Ipoh closed down in 1930 due to capital inefficiency and the collapse of tin prices brought by the Great Depression (Tan 1953; Yen 2008). Banking was one of the manifestations of Chinese dialect identity and competition in economic life as each dialect group excelled in a particular sector of the economy. On the other hand, there was an Indian-owned bank, the Oriental Bank of Malaya, established in 1936. The main function of this bank was limited to handling remittances from members of the Ceylonese community working in Malaya. A Malay-owned bank, the Malay National Banking Corporation, was also established in 1947 which undertook hire purchase business in sewing machines, motor vehicles, sarongs and musical instruments. 
It failed in 1952 due to the lack of banking experience of its directors and staff and its small capital (Lim 1967).

In Sarawak, a few Chinese banks were established. All these banks were traditional in their style of management and conservative in operation, being concerned with meeting the needs of local business groups rather than getting involved in international trading, particularly with the West (Tan 1982). For instance, Bian Chiang Bank was established in Kuching in 1924 by a Hokkien prominent businessman, Wee Kheng Chiang. In its early days, the Bian Chiang Bank's activities were mainly related to business financing and the issuance of bills of exchange to the Chinese business community in Sarawak. ${ }^{2}$ Kwong Lee Bank, a Cantonese-owned bank started operation in 1905 in Kuching, Sarawak under the name Kwong Lee Mortgage \& Remittance Company. The company granted loans against the security of export commodities such as pepper, rubber and other indigenous products. It also provided the services of remitting money of overseas Chinese to their families in south-east China. It later incorporated as Kwong Lee Bank Ltd in 1934. Another bank, Wah Tat Bank, was established in 1955 by two of the most prominent Hokkien families. Meanwhile, Hock Hua Bank established in 1952 represented the interests of the Foochow people, emerging as a joint venture of several Foochow entrepreneurs and a large number of small investors to provide loans to Foochow farmers and traders that had been refused by the Kwong Lee Bank and Wah Tat Bank (Ngu 2012). These largely dialect-based banks were small and accounted for only a third of the total deposits in Malaya and Borneo in 1955; the rest was held by the British-owned Chartered Bank, Hong Kong and Shanghai Bank and the Mercantile Bank (Supriyah 1984: 31). These family-owned, Sarawak-based banks were conservative in their management and reluctant to expand beyond the state for fear of dilution of their interests (Chen 2013), which eventually restricted their growth and so they eventually became targets of acquisitions. Table 1 provides a summary of the establishment of these early banks.

Chinese family-owned banks developed and flourished in the 1960s and played significant roles in funding the development of Chinese businesses and for nation building. Nonetheless, this era also witnessed the emergence of 'national banks', which included shareholders of different ethnic groups in Chinese-controlled banks and the establishment of state-owned banks. Chinese businessmen who made their fortunes in the rubber and tin industries diversified into the financial sector and facilitated industrial and property development activities (Tan 1982:159). 
TABLE 1: Early Commercial Banks (Locally incorporated)

\begin{tabular}{|l|l|l|}
\hline Name of Bank & $\begin{array}{l}\text { Places and year of } \\
\text { incorporation }\end{array}$ & $\begin{array}{l}\text { Ethnic/dialect } \\
\text { affiliation }\end{array}$ \\
\hline Kwong Yik (Selangor) Bank & Kuala Lumpur, 1913 & Chinese-Cantonese \\
\hline Bank of Malaya $^{\text {a }}$ & Ipoh, 1920 & Chinese-Cantonese \\
\hline Batu Pahat Bank $^{\text {Batu Pahat, 1920 }}$ & Chinese-Hokkien \\
\hline Kwong Lee Bank $^{\mathrm{b}}$ & $\begin{array}{l}\text { Kuching, Sarawak, } \\
\text { 1934 (1905) }\end{array}$ & Chinese-Cantonese \\
\hline Bian Chiang Bank & $\begin{array}{l}\text { Kuching, Sarawak, } \\
1956(1924)^{c}\end{array}$ & Chinese-Hokkien \\
\hline Ban Hin Lee Bank & Penang, 1935 & Chinese-Hokkien \\
\hline Oriental Bank of Malaya & Kuala Lumpur, 1936 & Indian \\
\hline $\begin{array}{l}\text { Malay National Banking } \\
\text { Corporation Ltd }\end{array}$ & Kuala Lumpur, 1947 & Malay \\
\hline Hock Hua Bank & Sibu, Sarawak, 1951 & Chinese-Foochow \\
\hline Wah Tat Bank & Sibu, Sarawak, 1955 & Chinese-Hokkien \\
\hline
\end{tabular}

a Bank of Malaya operated from 1920 to 1930.

b Started as Kwong Lee Mortgage and Remittance Company in 1905.

c On 24 December 1956, Bian Chiang Bank was incorporated under the name of Bian Chiang

Bank Ltd.

${ }^{\mathrm{d}}$ Malay National Bank operated from 1947 to 1952.

Source: Compiled from Tan (1953), Lim (1967), Lee (1990) and Cheah (2011).

At that time, with a Chinese finance minister, it was not difficult for the Chinese to obtain a banking licence. Several Chinese banks that were incorporated included the United Malayan Banking Corporation (1960), Malayan Banking (1960), Hock Hua Bank (1961) in Sabah, Southern Bank (1962), Development and Commercial Banking (1965), Kong Ming Bank (1965) and Public Bank (1966) (Hara 1991; Tan 1982). As the banking industry expanded in the 1960s, there were some M\&As. In 1964, the Overseas-Chinese Banking Corporation (OCBC) of Singapore acquired a 52 per cent majority stake in Kwong Lee Bank. OCBC was established in 1919 by Chinese Singaporean businessmen in Singapore to facilitate the growing financial needs of the local Chinese community.

As economic development continued to move faster and with greater intensity and on a much broader economic base, dialect, clan and other traditional Chinese characteristics began to give way in the 1960s. During this period, spatial and occupational mobility became more common and greater integration occurred among Chinese through intermarriage between different dialect/clan groups, which marked the beginning of the diminishing influence of dialect/clan relationships. 


\section{Emergence of National Banks and State-Owned Banks and the Decline of Chinese-Owned Banks}

Until the 1970s, 'all of Malaysia's local banks (with two or three exceptions) were synonymous with Chinese business' (Hara 1991: 350). During this period, the presence of many small banks, predominantly Chinese family owned and other retail enterprises, gave an impression that the Chinese were dominating the Malaysian economy. In actuality, as of 1970, Chinese ownership of the Malaysian banking sector was 24.3 per cent, which was far higher than the Malays (3.3 per cent) but much less than that by foreigners (52.2 per cent) (Malaysia 1973: 83).

It was widely argued that the uneven distribution of wealth among different ethnic groups in Malaysia, largely between ethnic Chinese and ethnic Malays, was the principal factor that led to riots in May 1969. Following this tragedy, a redistributive policy was introduced in the form of the NEP, with a two-pronged strategy: to eliminate poverty and to restructure Malaysian society in a timeframe of two decades (1971-90). The second prong of the NEP's spirit has had great and lasting impacts on Malaysia's banking sector, especially in the context of increased economic globalization which has seen rapid changes of ownership and identities in Malaysia's local banks.

Two 'national' and 'multi-ethnic' banks emerged in the 1960s: Malayan Banking Berhad (MBB) and United Malayan Banking Corporation (UMBC). MBB was founded by Khoo Teik Puat and UMBC by Chang Min Thien. These banks did not have the baggage and liabilities of the old guard. They were not dialect based and were not identified with particular clans within the Chinese community. They were considered multi-ethnic banks in terms of ownership as well as their customer base. A government-owned bank, the Bank Bumiputra Malaysia Berhad (BBMB) was incorporated in 1965 as the first Malay commercial bank. Given the weak economic position of the Malays and the fact that Chinese-owned banks were exclusive, the establishment of BBMB was to break Chinese dominance in the banking industry and also aimed to increase capital loan options to bumiputera individuals and companies (Snodgrass 1980: 53) as ways to advance a bumiputera entrepreneurial class.

To achieve the nation's wealth retributive policy, the NEP systematically reshaped the country's banking sector. Malaysia's banking policies and reform of the banking sector have been an integral part of the NEP, intending to restructure Malaysian society in terms of wealth distribution. To further the NEP's social engineering of a Malay entrepreneurial class, 
Bank Negara, the central bank, seized an opportunity in December 1966 and took control of MBB when it was faced with management problems and in danger of collapse. MBB was eventually put under government protection (Ranjit 1987), so the central bank had used its discretionary power to take control of a bank. MBB remains state owned. Thus, the Malaysian Chinese had not only lost control of the largest local bank but also the identity of that bank. Currently, MBB is Malaysia's largest state-owned bank or government-linked company with majority bumiputera interests.

Following the central bank's takeover of MBB, the bumiputera capital ownership, including trust agencies, collectively owned 60 per cent of overall equity share in the domestic banking and finance companies by 1980. This figure had increased to 69 per cent by June 1985 (Malaysia 1986: 110). A study by Fujio Hara (1991: 353) shows that bumiputera ownership had increased to 77 per cent for the whole Malaysian banking industry by early 1982. The Chinese had lost out permanently in many of the Chinese-controlled banks, and despite the banking identity being synonymous with the Chinese community.

The debt crisis of the 1970s and late 1980s and financial sector liberalization pushed Malaysian banking institutions through a consolidation process to meet the requirements of the central bank, which aimed to improve the banking industry's competitiveness and to encourage the emergence of more professional management through the dilution of individual ownership. The central bank's view was that small Malaysian banks would not be able to survive once the financial market was liberalized following the commitment under the General Agreement on Trade in Service in the World Trade Organization (Jayasankaran 1997). This period marked the beginning of the disappearance of some Chinese-dialect banks.

As of 1990, only eight of the 14 Chinese-controlled banks were left, six Chinese-controlled banks had been taken over by the state or by bumiputera interests (Hara 1991). Chinese ownership of Malaysia's banking sector has declined from 24.3 per cent in 1970 to 10.2 per cent in 2004 (Malaysia 1973: 83; Malaysia 2006: 338, 357). Simultaneously, more and larger state-owned banks are expanding their presence in the domestic markets and beyond.

The AFC was another acid test for Malaysian banks. Against the backdrop of the AFC, many Asian countries underwent massive reforms in their financial sector. The AFC affected the financial sectors of Indonesia, Thailand, Malaysia and the Philippines but with varying magnitude. Following the crisis, each country adopted a push for local 
bank consolidation. To enhance competitiveness, the Malaysian government pressed on with liberalization by getting local banking groups to consolidate among themselves, rationalize common functions and operations across institutions and outsource non-core activities. Among the four countries, Malaysia took the strongest state-guided approach and entirely reformed the domestic banking sector in the post-AFC years. To defend its affirmative or redistributive policy and protect against external shocks, the state adopted a gradualist approach towards financial liberalization (BNM 1999). Beck and Levine (2004) argue that when global trade has become more integrated, and the financial sector becomes more globalized and exposed to external shocks, states will probably adopt proactive policies in the financial sector that could generate growth through mobilizing of resources towards more efficient use. For Malaysia, Cook (2008: 67) contends that before, during and after the AFC, the Malaysian government took a very concerted defensive approach to the forces of banking sector globalization; state and stateaffiliated banks remained in the government's favour. Cook argues that Malaysia's statist-nationalist banking policy remained steadfast and was the most resilient to pressure of globalization and protected until the present day. Such a policy has resulted in the increased size of stateowned banks through M\&A and a decrease in ethnic and family-owned small and medium-sized banks.

The result was the formation of ten anchor banks from a total of 54 financial institutions as at end of 2001. The aim then was to streamline the banking industry to withstand competition from large foreign banks in the process of liberalizing the domestic financial sector. In this context, small Chinese-controlled banks were absorbed into bigger banks and disappeared from the corporate scene. The ten anchor banks are: Malayan Banking, Bumiputra-Commerce Bank, Public Bank, RHB Bank, Arab-Malaysian Bank, EON Bank, Multi-Purpose Bank, Hong Leong Bank, Affin Bank and Southern Bank. The government-initiated banking consolidation plan commencing on 1 July 2000 resulted in a complete reform of the Malaysian banking sector. Cook (2008) notes that from the late 1960s until the present, the government has always been very firm with its state-guided approach and had systematically reformed the domestic banking sector. Today there are only two Chinese-controlled or family-owned banks left in Malaysia, namely Public Bank and Hong Leong Bank.

Nonetheless, as of early 2000s, Malaysian local banks are considered too numerous and not competitive enough compared to foreign banks. 
Moreover, mergers of commercial banks with investment banks and finance companies have not achieved the desired economies of scope and scale (Randhawa 2011: 410). In mid-2014, an exercise of forming a Malaysian mega-bank was proposed and led by CIMB Group Holdings Berhad, Malaysia's second-biggest bank, to merge with RHB Capital Berhad and Malaysia Building Society Berhad (MBSB) to create Malaysia's largest bank. Its assets of RM629 billion would surpass Malaysia's largest lender, Malayan Banking Berhad's RM583.4 billion assets. ${ }^{3}$ This new development indicates a trend towards fewer and larger banks in Malaysia. Conversely, given the history of CIMB (controlled by UMNO (United Malay National Organization) politicians) and RHB (controlled by well-connected businessmen), which continue to struggle for control over Malaysia's financial sector, political observers perceived that 'this consolidation will tightly entwine the interests of political and business elites in the banking sector'. ${ }^{4}$ The mega-bank proposal also implies that the remaining two Chinese or family-owned banks will go, most probably moving in the same direction towards M\&A to become not only larger but also changing identity from 'Chinese-ness' to simply national banks with reduced Chinese or family ownership.

The external shocks of the 1980s and 1990s clearly show the increasing power of global forces and growing pressure on Malaysia's financial sector reform, which is shaping Malaysian banks' ownership and identities. These two external shocks revealed that the government had a strong hand that favoured state and bumiputera interests in the domestic banking sector. The state's policy was seen as driven by the market forces of globalization but had never lost sight of the NEP's redistributive policy. However, the GFC witnessed a different form and scale of acquisitions by Malaysian banks, which were driven by market forces and were mostly cross-border acquisitions. These took place before, during and throughout the protracted crisis periods. During these periods, acquisitions by Malaysian banks involved not only banks in the ASEAN region but also western investment banks in the Asia-Pacific region when they were greatly affected by the GFC. Asian lenders, including Malaysian banks, perceived the 2008 GFC as a global economic power shift to the ASEAN region and they seized opportunities to capture strategic and valuable deals. The GFC had significantly reduced the number of banks owned by OECD countries in the Asia-Pacific. Conversely, the number of foreign banks from emerging markets were on a fast track of growth which had shifted the ownership structures of regio nal banking groups (Claessens and Horen 2014). Under the ASEAN Banking Integration 
Framework (ABIF), such a phenomenon has deepened financial integration for ASEAN to achieve ASEAN-wide banking sector liberalization by 2020 (Almekinders et al. 2015).

\section{From 'National' and State Owned to Global Banks}

This section describes how three of the largest state-owned and bumiputera-controlled banks (Malayan Banking, CIMB Bank and RHB Bank) have evolved from a rich Chinese banking tradition with a strong banking foundation. These three state-owned banks are growing in size, expanding their presence in ASEAN markets and beyond to become global banks.

The government's policy to promote modern domestic commercial banking, through measures such as the increased capital requirements by the central bank, effectively reduced the number of Chinesecontrolled banks. As with state-owned banks, these three Chinesecontrolled banks also expanded, increasing their cross-border banking activities through the acquisitions of foreign banks in connected markets, but were less aggressive compared to state-owned banks. As the size of their assets increased, they became difficult targets for acquisition as Malaysia's banking policies clearly favoured state-owned banks and bumiputera interests. Under the protracted affirmative policy (see Chin and Teh 2017), Public Bank (PB) and Hong Leong Bank (HLB) have been able to gain government favour by conforming to government policies. However, the founders and Chinese ownership in these banks have declined over years but still retain management control. A recent study claims that 'paternalism, personalism and insecurity still exist' among Malaysian Chinese-controlled banks (Koh 2018: 63). In the context of Malaysia's affirmative action policy, 'insecurity' is always perceived as closely related to the statist policies where the remaining Chinese-controlled banks are always the targets for either merger or acquisition. Therefore, Chinese-controlled banks are always conservative rather than aggressive, like the three state-owned banks mentioned above. With significantly reduced family ownership and increased state interest, these Chinese-controlled banks have gradually become 'national banks' and global banks.

The following section describes the history, formation, development, consolidation, regional expansion and identities of Malaysia's five largest local banks.

\section{Malayan Banking Group}


Malayan Banking Berhad or Maybank is Malaysia's largest bank, among Asia's leading financial services groups and the fourth-largest banking group in Southeast Asia, with assets of RM807 billion as of December 2018. It has relatively shorter Chinese roots and tradition compared to the CIMB Group and RHB Group. Maybank was founded by Khoo Teck Puat in 1960 shortly after he left the OCBC group in Singapore. Khoo was a prominent businessman and his father owned stakes in the OCBC. Khoo controlled the Goodwood group of hotels and held significant stakes in the London-based Standard Chartered Bank. He established Maybank with 80 former OCBC staff and within six years Maybank had opened more than 100 branches in Malaya, Singapore, London and Hong Kong. In 1963, as managing director and chief executive of Maybank, Khoo financed his property investments, which include Goodwood Park Hotel for SGD4.8 million. Due to this impropriety, Khoo lost his position as managing director of Maybank. In December 1969, the Malaysian Central Bank effectively took control of Maybank (Ranjit 1987).

In the course of the post-AFC and state-directed banking consolidation, Pacific Bank and Phileo-Allied Bank (PAB) merged with Maybank in 2001. Pacific Bank Berhad was incorporated as a wholly owned subsidiary of the OCBC in 1963 after OCBC acquired the Bank of Batu Pahat Limited, which was established in 1920. PAB was founded in 1995 by Tong Kooi Ong and has shareholders of different ethnic groups with Avenue Assets Berhad (formerly known as Phileo Land Berhad) owning 18.52 per cent of $\mathrm{PAB}$. Avenue Assets Berhad is a diversified conglomerate controlled by Mokhzani Mahathir, son of Malaysian Prime Minister Mahathir Mohamad (Phileo-Allied Group Annual Report 2000: 95). ${ }^{5}$ Some analysts viewed that Tong secured a banking licence to establish PAB because he was linked to Anwar Ibrahim, then finance minister. The forced sale of PAB came right after Anwar's fall from power and the banking consolidation initiative in the immediate post-AFC. Tong was the first to develop online banking through the PAB. Recently, Tong has said on his blog:

In 1995 when Phileo-Allied Bank introduced online banking and stockbroking, the Kuala Lumpur Stock Exchange (KLSE) tried to stop this innovation by going to the courts. The reason was to protect their market share and commission rates. And after the successful launch of OneAccount in 1996, the first current account that pays fixed deposit interest rates, Bank Negara stopped the launch of the OneCorporate account that would have given companies the same benefit. A few large banks protested. In the name of consolidation of the banking sector, an innovative, technologically superior and profitable bank was forced to be sold in $2001 .{ }^{6}$ 
Since the central bank took control of Maybank in 1966, it has remained a state-owned bank. As of the end of 2018, Permodalan Nasional Berhad (PNB) owns 48 per cent of Maybank. PNB is a government investment fund established in 1978 as a principal vehicle of the government to achieve the NEP's objective of societal restructuring by promoting share ownership in the corporate sector among the bumiputera. PNB is Malaysia's largest fund management company with assets of RM298.5 billion. (PNB Annual Report 2018)

So, Maybank has created for itself a new brand across Asia and beyond. It launched a new brand campaign in 2014 with the theme 'Bridging Worlds in Asia' in the competitive banking landscape. Maybank was already a regional bank in 1960 when it was established in Malaysia. Today, with more than 2,600 offices in 18 countries, it connects many across Asia in terms of their financial needs. The Maybank brand has a presence in all ten countries of the ASEAN, the three global financial centres of Hong Kong, London and New York, the two biggest emerging markets of China and India, the Middle East and other countries. Maybank is one of the top 500 most valuable global brands. ${ }^{7}$

Maybank has been on an accelerated track of acquisition since the mid-1990s, buying stakes in other banks of different regions to stay competitive as the financial sector is increasingly globalized. Maybank has a strong presence in Indonesia, Singapore and the Philippines. It has been operating in Singapore since it was incorporated in 1960. In 2011 Maybank strengthened its securities business by acquiring Singapore brokerage firm Kim Eng Holdings Limited, adding a new entity to its Malaysian investment banking operation, Maybank Investment Bank Berhad. The acquisition of Kim Eng gives Maybank instant access to investment operations in Singapore, Thailand, Vietnam, Indonesia and the Philippines. Maybank perceived Kim Eng as a perfect complement to its existing strengths in investment banking and the equities market to transform Maybank into a regional powerhouse. ${ }^{8}$ Now the Maybank Kim Eng Group has offices across Southeast Asia, the USA and UK. It has been involved in several high-profile deals in the region. As at December 2018, Maybank's total assets in Singapore were SGD73.3 billion.

The Maybank brand entered the Indonesian market in 1995 when it commenced a joint-venture with PT Bank Nusa Nasional. Maybank has gained greater visibility in Indonesia after its acquisition of PT Bank International Indonesia (BII) from Temasek (Singapore's state-owned investment company) and Kookmin (South Korea's biggest bank) who jointly hold a controlling interest of about 55.6 per cent. Subsequently, Maybank secured 97.5 per cent of BII in a deal amounting to US\$2.7 
billion. The acquisition took place when global bank stocks had plummeted by 33 per cent in 2008. ${ }^{9}$ Its presence in the Philippines began in 1997 after it acquired PNB Republic Bank in 1997 and renamed the bank as Maybank Philippines Inc. Maybank as a financial group is growing in size, increasing its presence in the region and beyond. In this it has some similar development strategies to those of the CIMB Banking Group and RHB Banking Group, which have rapidly expanded their international investment banking operations.

\section{CIMB Bank Group}

CIMB Bank Group, with assets of RM534.1 billion, is Malaysia's secondlargest bank and the fifth-largest banking group in Southeast Asia. It is one of the largest Asia-Pacific investment banks (excluding Japan) and a leading ASEAN universal bank (CIMB Annual Report 2018). CIMB is an ASEAN catalyst that has a footprint across all ten ASEAN countries, connecting people and markets for economic growth.

CIMB is state owned, with Khazanah Nasional Berhad, Employee Provident Fund and Pension Fund as substantial institutional shareholders. CIMB has a strong Chinese heritage in banking that can be traced back to the establishments of Bian Chiang Bank (BCB), Ban Hin Lee Bank and Southern Bank. CIMB also has a Malay root and tradition that can be traced to the establishment of Bank Bumiputera Malaysia Berhad (BBMB). BBMB has a 'Chinese touch'. In its formative years, prominent Chinese businessmen Robert Kuok and Khoo Kay Peng were appointed directors in 1966 to assist the bank (Gomez 1999: 102). CIMB's early change of ownership and identity occurred when the Wee family who founded BCB sold their 36 per cent stake to UMNO-owned Fleet Group in 1975. Four years later (1979), the Fleet Group completed its acquisition of $\mathrm{BCB}$ and led to the formation of Bank of Commerce Berhad and retained the acronym brand name of BCB (Gomez 1990:36). By the 1980s, BBMB became the largest bank in the country in terms of assets and was the first Malaysian bank to have operations in New York, London, Tokyo, Bahrain and Hong Kong.

In October 1999, BBMB recovered from the AFC and other financial problems to merge with Bank of Commerce Berhad, resulting in the formation of Bumiputra-Commerce Bank (BCB), which was the biggest merger in Malaysian banking history under the control of Commerce Asset Holdings Berhad (CAHB). In 2005, CAHB announced its decision to create a universal bank by combining its commercial and investment 
banks. In an aggressive M\&A, in March 2006, CIMB launched a hostile takeover of Southern Bank, which was one of the ten anchor banks announced in 1999. Southern Bank is an enlarged Chinese-controlled bank with a strong foundation after it merged with Ban Hin Lee Bank in 2001, in the post-AFC banking consolidation process. CIMB Group recognized Southern Bank as an important player in wealth management products, credit cards and SME lending that are Chinese dominant. Southern Bank was the first in the country to set up the MEPS/ATM system used throughout Malaysia today. After enlarging its consumer banking sector, $\mathrm{BCB}$ was rebranded to have its current name, CIMB, in 2006. The takeover of Southern Bank added a valued niche player in consumer banking to the group. The merger combined the extensive resources of $\mathrm{BCB}$ with the expertise and agility of Southern Bank. The CIMB chief felt that CIMB needed to proceed with the takeover of Southern Bank to complement the banking franchise it was trying to build. It was a hostile takeover because Southern Bank had been an important ingredient in helping effect the turnaround in CIMB's consumer franchise. ${ }^{10}$ From this merger, CIMB formed a regional universal banking group that aims to be 'Southeast Asia's Most Valued Universal Bank' and embarked on a rebranding exercise including unveiling a new logo and a new tagline, 'Forward Banking', reflecting its promise to create value for customers through forward thinking. ${ }^{11}$ In other words, CIMB has created a new identity in the ASEAN countries.

A context of increased liberalization of the banking sector, in which size and efficiency matter, led the leadership of the CIMP Group to position itself as an ASEAN bank by building up its ASEAN franchise. It attempts to emulate the model of 'too big to fail' banks such as Goldman Sachs and JP Morgan of the United States, which have huge international investment banking operations. CIMB's expansion strategies are quite similar to that of Malayan Banking and RHB Bank. In 2004, CIMB formed 60:40 joint-venture with the Principal Financial Group of the USA, a New York Stock Exchange-listed global financial service company, which resulted in the formation of CIMB-Principal Asset Management Berhad (CIMB-Principal). CIMB-Principal has regional investment capabilities in Malaysia with a regional footprint covering Singapore, Indonesia and Thailand. Now CIMB was on a 'shopping spree' to expand its international investment banking operations. In 2005, it acquired GK Goh Securities Pte Ltd which led to the formation of CIMB-GK Securities Pte Ltd, strengthening CIMB's international investment banking operations. GK Goh was founded in Singapore in 
1979, evolving into a reputable Pan-Asian stockbroking franchise with operations in Singapore, Indonesia, Hong Kong, the UK and the USA.

CIMB Group also flexed its muscles during the 2008 GFC when almost all western banks of great size were forced to sell their operations abroad. Yet CIMB Group strengthened its presence in Southeast Asia and connected itself to global financial centres and large economies that have linkages with ASEAN. To achieve this aim, CIMB Group acquired a 19.99 per cent stake in the Bank of Yingkou in 2008, adding mainland China to the group's network. In the same year, CIMB Group created the sixth-largest bank in Indonesia after the group merged PT Bank Niaga Tbk with PT Bank Lippo Tbk. The merged bank was rebranded as 'CIMB Niaga' in Indonesia. Also in 2008, CIMB acquired a 93 per cent stake in BankThai PCL, which firmed up CIMB Group's universal banking platform across major ASEAN markets and made the Group's retail network the widest in ASEAN. BankThai was rebranded as 'CIMB Thai' and its new brand and logo were unveiled to the public in May 2009 as part of CIMB Thai's transformation into a financial institution that offers innovative products and services to the Thai market.

In September 2009, CIMB Group set up retail banking services in Singapore. The retail banking component complements CIMB Group's existing securities, advisory and corporate lending businesses in Singapore. Then in November 2010, CIMB Group spread to Cambodia. In April 2012, CIMB had purchased some of Royal Bank of Scotland's (RBS) Asian investment banking business in the Asia Pacific for US\$142 million. RBS's operations in Asia-Pacific markets include Australia, Hong Kong, Indonesia and Thailand. The acquisition aims to make CIMB one of the top three Southeast Asian banks in terms of assets and return on equity. In underwriting capital market deals for the Asia-Pacific, data indicate that CIMB beat DBS Group Holdings Ltd and HSBC Holdings Plc, while RBS trailed at number 35. For takeovers, it trumped Morgan Stanley, Credit Suisse Group AG and Goldman Sachs, with RBS lagging behind at number $19 .{ }^{12}$

CIMB Group is emerging as a top regional financier for mergers and acquisitions. In late 2012, CIMB provided some of the financing to Overseas Union Enterprise Ltd's S\$9 billion counterbid for Fraser and Neave Ltd. ${ }^{13}$ The deal marked CIMB Group as the top of the regional M\&As league in Southeast Asia for 2012. CIMB is also growing its crossborder M\&A deals. For instance, it helped to broker a billion-dollar deal which saw private equity firm CVC Capital Partners buying 98 per cent of PT Matahari Department Store, Indonesia's largest supermarket 
chain, owned by the Lippo Group. ${ }^{14}$ CIMB was also involved in the Songkhla-based Sri Trang Agro-Industry PCL and Malaysia Smelting Corp Berhad's listing on the Singapore Exchange and Genting Singapore Plc's S\$1.8 billion (US\$1.4 billion) perpetual bond sale in 2012.

As a state-owned bank, the lender is benefiting from Malaysian companies, especially state-owned companies, that are pushing ahead with initial public offerings (IPO) even as markets worldwide are affected by Europe's protracted debt crisis. CIMB was principal adviser and managing underwriter for the Malaysian portion of IHH Healthcare Berhad's US\$2.1 billion dual listing on the Kuala Lumpur and Singapore stock exchanges in July 2012. It helped raise US\$3.3 billion for Kuala Lumpur-based plantation owner Felda Global Ventures Holdings Berhad, Malaysia's biggest in 2012 IPO after Facebook's US $\$ 16$ billion share sale. IHH Healthcare Berhad, a Malaysian government-controlled company is Asia's largest hospital operator. Felda Global Ventures, also a Malaysian-government controlled company is the world's third-largest oil palm plantation operator.

CIMB follows in the footsteps of some large US banks in these regional markets. However, its three-way merger exercise to create Malaysia's largest bank in mid-2014 did not materialize.

\section{RHB Bank Group}

RHB Bank Group is the fourth-largest financial group in Malaysia, with total assets of RM243.2 billion (RHB Bank Annual Report 2018). It has the deepest Chinese heritage in finance and banking compared to Maybank and CIMB. RHB Bank started in 1997 from a merger between two Chinese founded banks - Kwong Yik Bank and D\&C Bank (Development and Commercial Bank). Kwong Yik Bank was Malaya's first local bank and D\&C Bank was founded by H.S. Lee in 1966. Lee was a well-known entrepreneur and the first minister of finance of Malaysia. D\&C Bank became the fifth-largest Malaysian bank by the late 1980s. In 1982, Maybank increased its share ownership of Kwong Yik Bank from 50.4 per cent to 51.4 per cent (Lee 1987: 328). In 1986 the Lee family surrendered management of D\&C Bank, following Lee's death. In 1990, Abdul Rashid Hussain, a politically well-connected corporate figure, bought a majority shareholding of D\&C Bank from the Lee family. In 1996, Rashid Hussain acquired a controlling stake in Kwong Yik from Maybank. A year later, Rashid merged Kwong Yik Bank and D\&C Bank and formed RHB Bank to become the third-largest integrated 
financial services group in Malaysia. RHB Banking Group recognized its founding year as 1913, which was same as that for Kwong Yik Bank (Selangor). The group celebrated RHB Bank's 100th anniversary in 2013. Internally, the group has built a diverse and performance-centric culture in its workplace.

RHB Bank can be traced to another Chinese-owned bank, the United Malayan Banking Corporation (UMBC). As of 1976, UMBC was Malaysia's third-largest bank, ranked after Maybank and Bank Bumiputera. UMBC was the first commercial bank established in independent Malaya in 1960 by a group of businessmen, led by Chang Ming Thien, a prominent figure in the rubber industry in Malaya and Singapore. Pernas (National Corporation), a wholly owned government company, through its growth strategies to indigenize key economic sectors in the country, seized the opportunity to obtain control of UMBC when it suffered the fate of Malayan Banking in 1966. UMBC ran into financial problems in 1976, which led to government intervention due to suspected frauds by the directors who had issued loans to companies owned by themselves. The subsequent restructuring of the bank gave even more opportunity for bumiputera to have larger share ownership in UMBC. In May 1985 the then Finance Minister Daim Zainuddin acquired outright control of UMBC and then sold it to Pernas for a lucrative profit in 1986. As of the early 1990s, Pernas has held an 85.7 per cent stake in UMBC and suffered massive loans taken to acquire the bank. Following this and the poor returns on this investment, Pernas was forced to sell UMBC in 1992 to Datuk Keramat Holdings, a bumiputera company that was without previous banking experience. After that the bank was involved in several financial improprieties, including disbursement of questionable loans. Sime Darby, a publicly listed but state-controlled conglomerate, bought UMBC in 1996 (Searle 1999: 74; Gomez and Jomo 1999). Sime Bank declared a loss of RM1.8 billion during the AFC. The troubled Sime Bank was then absorbed by RHB Bank in 1999. The processes of M\&A in RHB bank since its incorporation until the acquisition of Sime Bank indicate the preferences of the state and power of individual bumiputera such as Rashid Hussain that had gained control of a major slice of Malaysia's financial sector within a short period. The post-AFC banking consolidation led to the merger of Utama Banking Group (UBG) into the RHB Banking Group. This M\&A involved tough negotiations with RHB founder Rashid Hussain, who sold his entire 23.9 per cent stake to UBG in 2003. Under UBG group management, RHB went through a volatile period to deal with the group's debt restructuring plans, when 
it was without top management leadership. ${ }^{15}$

Since 2007, RHB Banking Group has been controlled by Malaysia's Employee Provident Fund. The restructured banking group has ambitions to be ASEAN's third-largest bank by 2020. RHB Group also has a regional expansion plan like Maybank and CIMB, that made their big foray into Indonesia during the 2008 GFC. In 2008, RHB Investment acquired a 49 per cent stake in Vietnam Securities Corp. RHB chose to be more cautious about spending too much. Its strategy was to acquire mid-sized banks such as PT Bank Mestika Dharma in Indonesia in 2009. However, it failed to get approval from the Financial Services Authority of Indonesia.

Just like Maybank and CIMB, the increased competition in the domestic market and the intensification of globalization of the financial sector has pushed RHB Banking Group to take an inorganic approach to expand its investment banking in the fast-growing Southeast Asian economies by acquiring OSK Holdings Berhad, a stockbroking company, in 2012. This acquisition gave an instant boost to RHB's investment banking operations in Southeast Asian markets such as Malaysia, Indonesia, Thailand, Singapore, Cambodia, Hong Kong and China. This strategy enabled the RHB Group to capture a surge in mergers and stock deals in Southeast Asia. This enlarged merged entity increases its ability to compete in Asia with global players such as Goldman Sachs and Morgan Stanley. RHB has grown in size and was ranked seventh in Southeast Asia for underwriting domestic bonds and eighteenth for share sales in $2013,{ }^{16}$ while in terms of assets it ranks thirteenth in 2019. ${ }^{17}$

\section{Public Bank Group}

The Public Bank Group is the third-largest banking group in Malaysia by asset size, with those standing at RM419.69 billion at the end of 2018 . During the NEP period, Public Bank pursued a bumiputera policy and was the first Malaysian local bank to have a Malay Chairman - Tan Sri Nik Ahmed Kamil, an influential member of the UMNO ruling party (Bowie 2006: 78: Tan 1982: 282). Most non-bumiputeras regarded the NEP as a disincentive but the founder of Public Bank Berhad (PBB), Teh Hong Peow, recognized its potential. Public Bank was accordingly granted 'Approved Status' by the finance minister for meeting all of the central bank's priority lending guidelines and for fulfilling the NEP's bumiputera ownership and employment quotas. Approved status also enables PBB to accept government deposits (Bowie 2006: 107). As early as 1980, it attained the prescribed goal, reaching a 31.2 per cent equity 
stake in the bank and consistent with the national agenda (Bowie 2006: 210). By abiding by its affirmative policy, PBB was given licences. By 1990 the bank had 90 bank branches and 78 finance company branches (Bowie 2006: 211, 214, 215).

PBB, as a well-managed bank, survived the ten critical anchor bank consolidation process of the domestic banking system post-AFC. It was the least affected among other local banks by the AFC and emerged relatively unscathed. Under the ten anchor bank consolidation directive, PBB acquired Hock Hua Bank in 2001. Public Bank also acquired Sime Merchant Bank in 2000 (Bowie 2006: 218, 266). Today, PBB is the largest non-governmentally linked bank and the fourth-largest company listed on the KLSE in terms of market capitalization. The Public Bank Group has two listed entities on the KLSE, namely PBB and Loanpac Insurance Berhad.

Since the 1990s PBB has been a regional bank. In January 1990, it made a significant move to acquire Public Finance Limited, Hong Kong (formerly known as JCG Finance Company Limited) as the bank's first overseas subsidiary. Since 1992, PBB has entered Sri Lanka, Vietnam and Cambodia. In late 1992 it became Malaysia's first bank to open a branch in Myanmar and the same in Laos. In June 2006, PBB reached another milestone in strengthening its regional ambition after it acquired Hong Kong's Asia Commercial Bank (ABC) for HK\$4.5 billion. ABC was renamed as Public Bank (Hong Kong) Limited and has 32 branches, with a branch in Shenzhen and representative offices in Shanghai and Shenyang, China. On the domestic front, PBB acquired Kuala Lumpur Mutual Fund Berhad in 1993 and renamed it Public Mutual. Public Mutual became a 100 per cent-owned subsidiary of PBB in July 2006. As of 2019, PBB has expanded its regional network to 265 locations, with 77 branches in Hong Kong, four branches in China, 31 branches in Cambodia, 18 branches in Vietnam, four branches in Laos and three branches in Sri Lanka.

The founder's ownership of the bank's equity had dropped from 48 per cent to 40 per cent during 1983-89, while the bumiputera share also decreased from 31.5 per cent to 25.9 per cent. Conversely, in the context of the state's relaxation of foreign participation in the domestic financial sector, foreign shareholdings in the bank rapidly increased from 18.5 per cent to 29.8 per cent in the same period (Hara 1991: 354). As of end 2013, the founder's total ownership of the bank had further decreased to 23.41 per cent (Public Bank Annual Report 2018: 261).

The pro-state and bumiputera bank policies coupled with potential external shocks led PBB to propose a RM5 billion rights issue, the larg- 
est by a local financial institution in recent years. This quantum cash call in May 2014 surprised the market. Even more surprising is that the founder and chairman subscribed his entitlement in full. The size of the fundraising indicates that the bank is fortifying its capital base beyond its requirements. This raises the question of why the 84-year-old banker would commit approximately RM1.2 billion of his own money to bolster the bank, which has been left to professional managers. According to the value of the bank, analysts calculated that a RM1.2 billion capital infusion by the founder will immediately triple its value to RM4 billion. The total amount raised has far exceeded the capital requirements under Basel III and the central bank's requirement, which means that the bank is now over-capitalized. Some bankers and analysts reason that the founder wants to ensure that he leaves PBB as his legacy and that the bank needs to be over-capitalized so it is able to overcome future economic downturns or certain regulatory requirements. The rights issue is aimed at strengthening PBB's capital base, in light of the implementation of the Internal Capital Adequacy Assessment Process, or ICAAP, and additional capital ratios imposed by the central bank and to avoid any eventualities of being controlled by the central bank in the future. ${ }^{18}$

\section{Hong Leong Bank Group}

The Hong Leong Bank Group is Malaysia's fifth-largest banking group with RM202.9 billion in total assets. It has sales and business centres in Malaysia, Singapore, Hong Kong, Vietnam, Cambodia and China (Hong Leong Bank Annual Report 2018). Hong Leong Bank Berhad (HLBB) has more than a century of experience in the mortgage and remittance industry since it was founded in 1905 in Kuching, Sarawak, under the name of Kwong Lee Mortgage and Remittance Company. It was incorporated as Kwong Lee Bank Ltd in 1934. The Lim family who founded the bank maintained their ownership and management until 1982, when the bank was acquired by Chinese tycoon Khoo Kay Peng, of the MUI Industry Group in Kuala Lumpur. The bank was renamed Malayan United Bank Berhad in 1983. Subsequently, it was renamed MUI Bank Berhad. The chairman of the bank in the early 1980s was Tunku Osman Tuanku Temenggong Ahmad, a member of the Johore royal family. Khoo realized that he would not be able to expand the bank's operations with the increased regulation of the sector. So, he divested his entire stake in MUI Bank in 1993 to Quek Leng Chan of the 
Hong Leong Group in Malaysia, which had been in the financial services industry since 1968 through Hong Leong Finance Berhad (Gomez 1999). The Hong Leong Group's acquisition of MUI Bank revealed Quek's close links with Anwar Ibrahim, the then finance minister, who exempted the takeover 'from complying with Malaysia's banking rules which limit the shareholdings of any individual corporate shareholder of a bank to no more than 20 per cent' (Gomez 1999: 155-156). MUI Bank was renamed Hong Leong Bank Berhad in October 1994.

The post-AFC state-led ten anchor bank consolidation ended Wah Tat Bank's operation after it became part of Hong Leong Bank in 2001. Another Chinese-owned bank, Kong Ming Bank founded by the late Ling Beng Sung in Sarawak in 1965, had become part of HLBB after the group acquired Edaran Otomobil Nasional (EON) Bank in 2011. Kong Ming Bank was sold to EON, the national Proton car distributor, in 1992 which marked the birth of EON Bank Berhad. ${ }^{19}$ The acquisition of EON Bank transformed HLBB into a banking group of more than RM170 billion in assets as of December 2013.

The Hong Leong group expanded its acquisitions abroad by acquiring two Hong Kong banks, the Dao Heng Bank in 1987 and then merging with Hang Lung Bank in 1989. In 1992, the group bought another Hong Kong bank, the Overseas Trust Bank. The group also acquired the Benchmark Bank Plc, renaming it Dao Heng Bank (London) plc. The group sold off its shares in Dao Heng Bank to Singapore's DBS Bank for RM10 billion (Gomez 1999: 154). HLBB's regional expansion has continued, as it bought a 19.99 per cent (RM877.5 million) stake in a small-sized commercial bank based in Chengdu, China in 2007 and became the first Malaysian bank to enter the Chinese banking sector. ${ }^{20}$ In the same year, HLBB entered the Vietnam market with a wholly owned commercial bank operation. In 2013, it began wholly owned commercial bank operations in Cambodia too.

\section{Conclusion}

Malaysia's protracted affirmative action policy in the economic sphere and the increased liberalization of the financial sector have led to four major changes in the number, size, structure of ownership and identities of Malaysian banks. First, the number of local banks has been reduced, small banks have disappeared, and both state-owned and Chinesecontrolled medium-sized domestic banks have grown to become largescale global banks that have spread their presence in ASEAN countries 
and beyond. Their size and cross-border expansion makes for more broad-based business activities, an ability to clinch big financial deals, increased capital base and opportunities to establish a regional brand which have deepened the financial integration of ASEAN countries.

Second, state protectionism of local banks in Malaysia that favoured state-owned banks and bumiputera interests resulted in the fading of the 'Chinese-ness' of banks, with them instead becoming national and regional banking groups or global banks. 'State-owned banks continue to have a significant presence in several ASEAN countries' (Almekinders et al. 2015: 13-14). As shown in this article, Malaysia is one of the ASEAN countries that has three state-owned banks expanding their presence in the region. All three state-owned banks discussed in this article adopt similar strategies, in that they have acquired strategic stockbroking companies - be these local or foreign - to expedite their regional presence in investment banking in ASEAN and beyond. However, Chinese-controlled banks are very careful with their expansion plans because they cannot afford to make any mistakes that may lead to the possibility of being controlled by the central bank.

Third, the 2008 GFC created a global economic power shift to the region, which prompted three of Malaysia's largest state-owned banks to seize opportunities to capture strategic and valuable deals while certain European banks were withdrawing their business operations in the region. This shows the power of the state; in the case of Malaysia, the state is resilient to the pressure of globalization of the financial sector. Conversely, meanwhile, 'foreign bank presence has become somewhat less global' (Claessens and Horen 2014: 22).

Fourth, in the context of a structural shift in the global banking system with the increased presence of banks from developing countries in ASEAN countries, a nation such as Malaysia shows its increasing role in the ASEAN economy and financial markets.

A final note for the awareness and attention of readers is that Malaysia's infamous 1MDB mammoth scandal had no impact on Malaysia's local banks, but it seriously affected two European banks' operations in Southeast Asia. 
CHIN YEE WHAH (PhD Universiti Kebangsaan Malaysia, 2002) is Professor of Economic Sociology in the School of Social Sciences, Universiti Sains Malaysia. His research interests include Chinese entrepreneurship, ethnic enterprise development, knowledge management, small and medium enterprises and industrial relations. His recent publications appear in Journal of Southeast Asian Economies (2018), Asian Journal of Social Science (2018), Malaysian Journal of Chinese Studies (2017) and Journal of Social Issues in Southeast Asia (2017).E-mail:ywchin@usm.my

\section{NOTES}

1 Formerly known as Bumiputera Commercial and Industrial Community or BCIC.

2 The prominent Wee family who founded Bian Chiang Bank were founding members of the United Overseas Bank in Singapore in 1971.

3 Bloomberg 2014. 'CIMB, RHB to Combinein\$22.3 Billion Three-Way Merger'. https://www. bloomberg.com/news/articles/2014-10-09/cimb-rhb-in-three-way-merger-to-formlargest-bank-in-malaysia.

4 KiniBiz 2014. 'The Politics and Business of Bank Mergers'. http://www.kinibiz. com/story/opinions/97360/the-politics-and-business-of-bank-mergers.html.

5 FinanceAsia 2000. 'Mahathir's Son Says No to Maybank Takeover'. https://www. financeasia.com/article/mahathirs-son-says-no-to-maybank-takeover/31212.

6 'Say No to Corporate Kings'. http://www.tongkooiong.com/2013/10/say-no-tocorporate-kings.html.

7 Akhyari Hananto. 2018. 'Southeast Asian Banks on the Rise: Most Valuable Banks in Southeast Asia 2018'. https:// seasia.co/2018/03/24/southeast-asian-banks-onthe-rise-most-valuable-banks-in-southeast-asia-2018.

8 The Edge Markets. 2011. 'Maybank Acquires Kim Eng'. https:// www.theedgemarkets.com/article/maybank-acquires-kim-eng.

9 Bloomberg 2008. 'Maybank to by Indonesian Bank as Temasek Renews Bid (Update2)'. http://www.bloomberg.com/apps/news?pid=newsarchive\&sid=aTHFJIhjSLV4.

10 The Star 2012. 'CIMB Poised to Emerge as Top Regional Financier for Mergers and Acquisitions'. https://www.thestar.com.my/business/business-news/2012/11/20/ cimb-poised-to-emerge-as-top-regional-financier-for-mergers-and-acquisitions/.

11 The Edge Markets. 2009. 'MMVB 2009: Delivering on Its Regional Promise'. https:// www.theedgemarkets.com/article/mmvb-2009-delivering-its-regional-promise.

12 Bloomberg 2012. 'CIMB Set to Take on Goldman with “Audacious" RBS Purchase'. https:// www.bloomberg.com/news/articles/2012-06-24/cimb-set-to-take-on-goldman-with-audacious-rbs-purchase.

13 OUE made the $\$ \$ 9.08$ per share offer, which works out to $\$ \$ 13.1$ billion for F\&N, countering the offer of $\mathrm{S} \$ 8.88$ ( $\$ \$ 9$ billion) per share made by Thai billionaire Charoen Sirivadhanabhakdi of the Pokphand Charoen group, who has interests in the food and agribusiness, retail and distribution as well as telecommunication industries.

14 The Star 2012. 'CIMB Poised to Emerge as Top Regional Financier for Mergers and Acquisitions'. https:/ / www.thestar.com.my/business/business-news/2012/11/20/ cimb-poised-to-emerge-as-top-regional-financier-for-mergers-and-acquisitions/. 
15 The Edge Malaysia 2009. 'Cover Story: Back in the Race'. https:/ / www.theedgemarkets.com/article/cover-story-back-race.

16 Bloomberg 2013. 'RHB Seeks Higher Regional Deals Ranking with OSK: Southeast Asia' https://www.bloomberg.com/news/articles/2013-04-29/rhb-seeks-higher-regional-dealsranking-with-osk-southeast-asia.

17 Revolvy.com. 'List of Largest Banks in Southeast Asia'. https://www.revolvy. com/page/List-of-largest-banks-in-Southeast-Asia.

18 The Star 2014. 'Teh's Extra Oomph for Public Bank'. https://www.thestar.com.my/ business/business-news/2014/05/03/tehs-extra-oomph-for-public-bank-foundertan-sri-teh-hong-piow-is-forking-out-rm12bil-as-part-of-the/.

19 The Edge Markets 2010. 'Cover Story: EONCap a Sitting Target for Predators'. https:/ / www.theedgemarkets.com/article/cover-story-eoncap-sitting-target-predators.

20 The Star 2007. 'HLB Buying into China's Chengdu Bank'. https://www.thestar. com.my/business/business-news/2007/10/26/hlb-buying-into-chinas-chengdubank/.

\section{REFERENCES}

Albert, S., \& Whetten, D. A. 1985. 'Organizational Identity'. Research in Organizational Behavior 7: 263-295.

Almekinders, Geert, Satoshi Fukuda, Alex Mourmouras, Jianping Zhou \& Yong Sarah Zhou 2015. 'ASEAN Financial Integration'. IMF Working Paper WP/15/34. Asia and Pacific Department, International Monetary Fund.

Bala Shanmugam and Mahendran Nair 2004. 'Mergers and Acquisitions of Banks in Malaysia'. Managerial Finance 30 (4): 1-18. https:/ / doi.org/10.1108/030743504107 68994

Balachandher K. Guru Mohan Avvari Balachandran 2004. 'Merger of Malaysian Banks: Selecting Appropriate Partners'. Managerial Finance 30 (4): 19-28. http://dx.doi. org/10.1108/03074350410769001

Bank Negara Malaysia (BNM) 1999. 'Management of the Banking System'. The Central Bank and the Financial System in Malaysia - A Decade of Change: 1989-1999. Kuala Lumpur. 1999: 181-228.

Beck, Thorsten and Ross Levine 2004. 'Stock Markets, Banks, and Growth: Panel Evidence'. Journal of Banking and Finance 28: 423-442. https:/ / doi.org/10.1016/S03784266(02)00408-9.

Bowie, Paddy 2006. Teh Hong Piow: A Banking Thoroughbred. Kuala Lumpur: Public Bank Berhad.

Cheah, Kooi Guan 2011. 'Early Commercial Banks in Malaysia: Rise, Decline and Metamorphosis'. Professorial Lecture Series 4 (4), University Tun Abdul Razak.

Chen, Tsung-Yuan 2013. 'Historical Institutional Analysis of Ethnic Financial Institutions: A Study of the Chinese Banks in Sarawak'. Malaysian Journal of Chinese Studies 2 (1): 49-67.

Chin, Yee Whah and Benny Teh Cheng Guan 2017. 'Malaysia's Protracted Affirmative Action Policy and the Evolving Bumiputera Commercial and Industrial Community'. SOJOURN: Journal of Social Issues in Southeast Asia 32 (2): 336-373. https:/ / doi. org/10.1355/sj32-2d.

CIMB Bank Annual Report 2018.

Claessens, Stijn and Neeltje van Horen 2014. 'The Impact of the Global Financial Crisis on Banking Globalization', International Monetary Working Paper WP/14/197. https://doi.org/10.5089/9781498301435.001. 
Cook, Malcolm 2008. Banking Reform in Southeast Asia: The Region's Decisive Decade. Abingdon, UK: Routledge. https://doi.org/10.4324/9780203926833.

Goode, William J. and Paul K. Hatt 1952. Methods in Social Research. New York: McGraw-Hill.

Gomez, Edmund Terence 1990. Politics in Business: UMNO's Corporate Investments. Kuala Lumpur: FORUM.

Gomez, Edmund Terence 1999. Chinese Business in Malaysia: Accumulation, Accommodation and Ascendance. Surrey: Curzon.

Gomez, Edmund Terence and Jomo, K. S. 1999. Malaysia's Political Economy: Politics, Patronage and Profits. Cambridge: Cambridge University Press.

Hara, Fujio 1991. 'Malaysia's New Economic Policy and the Chinese Business Community'. The Developing Economies 29 (4): 350-370. https:/ / doi.org/10.1111/j.17461049.1991.tb01040.x.

Hong Leong Bank Annual Report 2018.

Ito Takatoshi and Hashimoto Yuko 2007. 'Bank Restructuring in Asia: Crisis Management on the Aftermath of the Asian Financial Crisis and Prospects for Crisis Prevention - Malaysia'. RIETI Discussion Paper Series 07-E-039, Research Institute of Economic, Trade and Industry, Japan.

Jayasankaran, S. 1997. 'Malaysia: Hit the Breaks'. Far Eastern Economic Review 18: (December) 14-15.

Jomo, K. S. 1994. U-Turn? Malaysian Economic Development Policies After 1990. Townsville: James Cook University of North Queensland.

Koh, Eric Hsieng Yang 2018. 'Chinese-ness Legacy? A Study of Ethnic Chinese Entrepreneur-controlled Banks in Malaysia'. International Journal of China Studies 9 (1): 49-66.

Khoo, Kay Kim 1988. 'Chinese Economic Activities in Malaya: A Historical Perspective'. In M. Nash (ed.), Economic Performance in Malaysia: The Insider's View. New York: Professors World Peace Academy, 1988: 179-223.

Lee, Hock Lock 1987. Central Banking in Malaysia: A Study of the Development of the Financial System and Monetary Management. Singapore: Butterworths.

Lee, Sheng Yi 1990. The Monetary and Banking Development of Singapore and Malaysia. 3rd ed. Singapore: Singapore University Press.

Lim, Chong Yah 1967. Economic Development of Modern Malaya. Kuala Lumpur: Oxford University Press.

Malaysia 1973. Mid-term Review of the Second Malaysia Plan 1971-1975. Kuala Lumpur: National Printing Department.

Malaysia 1986. Fifth Malaysia Plan 1986-1990. Kuala Lumpur: National Printing Department.

Malaysia 2006. Ninth Malaysia Plan 2006-2010. Kuala Lumpur: National Printing Department.

Maybank Annual Report 2018.

Muhamed Zulkhibri Abdul Majid and Fadzlan Sufian 2006. 'Consolidation and Competition in Emerging Market: An Empirical Test for Malaysian Banking Industry'. Economic Change and Restructuring 39 (1\&2): 105-124. https://doi.org/10.1007/ s10644-007-9022-4.

Ngu, Ik Tien 2012. Maintaining Domination: State Power and Local Politics in Sibu, Sarawak, 1945-2011. PhD thesis. Universiti Sains Malaysia.

Phileo Allied Bank Annual Report 2000.

Public Bank Annual Report 2018.

Randhawa, Dipinder Singh 2011. 'Banking and Capital Market Reforms in Malaysia'. ASEAN Economic Bulletin 28 (3): 388-413. https:/ / doi.org/10.1355/ae28-3g. 
Ranjit, Gill 1987. Khoo Teck Puat: Tycoon on a Tightrope. Singapore: Sterling Corporate Services.

Remolona, Eli and Ilhyock Shim 2015. 'The Rise of Regional Banking in Asia and the Pacific'. BIS Quarterly Review (September): 119-134.

RHB Bank Annual Report 2018.

Searle, Peter 1999. The Riddle of Malaysian Capitalism: Rent-seekers or Real Capitalism? NSW: Allen and Unwin.

Snodgrass, Donald R. 1980. Inequality and Economic Development in Malaysia. Kuala Lumpur: Oxford University Press.

Supriya Singh 1984. The First 25 Years: 1959-1984. Kuala Lumpur: Bank Negara Malaysia.

Syed Zamberi Ahmad 2012. 'The Internationalisation of Malaysian based Multi national Banks'. Asia-Pacific Journal of Business Administration 4 (1): 58-81. https:/ / doi. org/10.1108/17574321211207971.

Tan, Ee Leong 1953. 'The Chinese Banks Incorporated in Singapore and the Federation of Malaya'. Journal of the Malayan Branch of the Royal Asiatic Society 26 (1): 113-139.

Tan, Tat Wai 1982. Income Distribution and Determination in West Malaysia. Kuala Lumpur: Oxford University Press.

Tschoegl, Adrian E. 2001. 'The International Expansion of Singapore's Largest Banks'. Working Paper 01-02, The Wharton Financial Institutions Center, University of Pennsylvania.

Yen, Ching Hwang 2008. The Chinese in Southeast Asia and Beyond: Socioeconomic and Political Dimensions. Singapore: World Scientific. https://doi.org/10.1142/978981 2790484. 